\title{
COUNTING GAME APPLICATION FOR KINDERGARTEN CHILDREN
}

\author{
Teri Ade Putra ${ }^{1)}$, Raja Ayu Mahessya ${ }^{2)}$, Yesri Elva ${ }^{3)}$, Pradani ayu widya purnama ${ }^{4)}$ \\ ${ }^{12345}$ Universitas Putra Indonesia YPTK Padang, Padang \\ Email: teriputra2@gmail.com
}

\begin{abstract}
Problems The development of Information Technology plays an important role in human life. With the development of Information Technology, humans can easily get information and humans can easily carry out daily activities with the help of existing technology. This Counting Learning Quiz Game Application for Kindergarten Children is designed to help students learn more fun so that they are easy to accept and understand when learning to use the application. With this application, children's ability to calculate is $68 \%$ faster than the manual method. so this study concludes that the application of technology in the form of games can help children understand faster.
\end{abstract}

Keywords: Information Technology, Android, Applications

\section{INTRODUCTION}

Many of the things we find in science are especially about the problems that one of them can be classified into forecasting(Amorim et al., 2022). In the seven years since the launch of the tablet (Apple iPad) in 2010, the use of smart device software has spread rapidly and has become a hot topic in child education and development (Papadakis et al., 2018). Computer programming is considered an important competence for the development of higher-order thinking in addition to algorithmic problem-solving skills. Its horizontal integration throughout all educational levels is considered worthwhile and attracts the attention of researchers (Fessakis et al., 2013). Although a myriad of educational applications using tablets and multi-touch technology for kindergarten children have been developed in the last decade, most of these applications do not fully exploit multi-touch technology since the game world used is limited to the screen only(Nacher et al., 2019).

Early number skills are critical predictors of academic achievement, which is why focusing on their instruction from the very beginning of education is recommended. Young children's number knowledge is also strongly influenced by home numeracy practices(de Vries et al., 2021).

Researchers have shown that children's social-emotional growth is inextricably connected to academic learning. We developed the Social-Emotional Learning Foundations (SELF) intervention, a Grade K-1 curriculum merging social-emotional learning (SEL) and literacy instruction, to promote language-supported selfregulation, specifically for primary grade children at early risk for emotional or behavioral difficulties(Daunic et al., 2021).

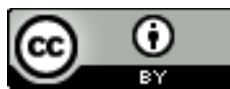


The development of understanding the important and unimportant aspects of counts in children ranging from 5 to 8 years of age. Essential aspects, such as logistical rules, and non-essential aspects, including conventional rules, are studied. To work around this, we created a program in which children saw counting errors (abstractions and irrelevant sequence errors) and pseudo-errors (with and cardinal errors) that occurred during the detection task. (Rodríguez et al., 2013). The direct manipulation interaction style of multi-touch technology makes it the ideal mechanism for learning activities from pre-kindergarteners to adolescents(Nacher et al., 2015) Parental support, emotional support, and contingency are encoded in parent-child interactions(Zhang \& Whitebread, 2017).

According to current kindergarten curricula, the gameplay is an important basis for children development and it is the main driving force when designing educational activities during early childhood(Nacher et al., 2016)

\section{RESEARCH METHODS}

Determining the object of research is a very important thing for a researcher before researching because it is from the object of research that researchers can obtain data that is used as material for conducting research. Based on this, the authors set the research location at Mekar Tigo Jangko Kindergarten. In collecting data at Mekar Tigo Jangko Kindergarten, I was a writer who conducted interviews to obtain information, by conducting direct interviews with school principals and with existing teachers. Data collection was done by direct observation to the field and conducting interviews with teachers at Kindergarten, and several students. Literature research is carried out by finding and collecting data and reading books related to the research being carried out. To conduct research, the author analyzes the data that has been collected and analyzes the system that will be run as a solution to the formulation of the problem obtained.

Analysis, which is the initial stage where the data collection process, a problem, problem-solving to build applications is carried out. Design, which is doing the design to make the system design as desired. Coding, which is implementing the results of the design into a programming language that can be read and understood by computers. Testing, namely the program must be tested which is focused on system activities that all existing commands have been tested and function properly to ensure that the commands entered are by the results issued.

\section{RESULTS AND DISCUSSION}

\section{Splash Screen Display}

The Splash Screen display is the initial display or can be referred to as an intro when the application is run.

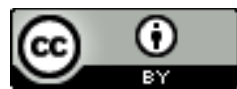




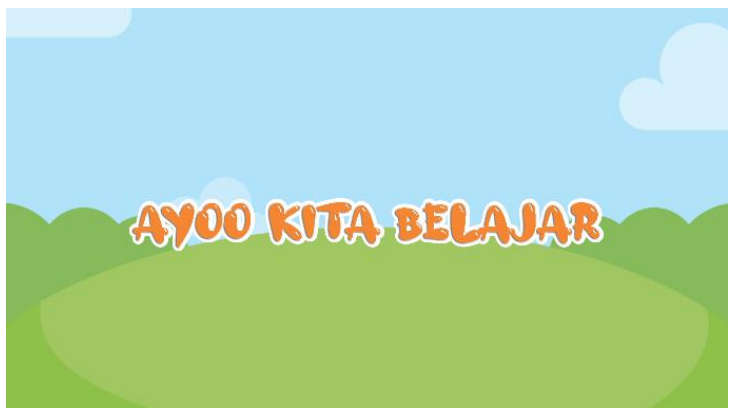

Picture 1. Splash Screen

The menu display is the initial display after the splash screen, this menu display can also be called home, the menu display has several buttons such as audio buttons, close buttons, info buttons, buttons to the learning menu.

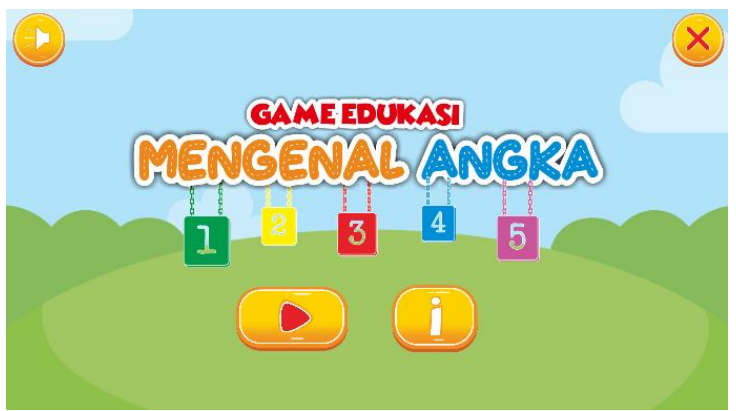

Picture 2. Menu Display

This menu will display the learning menu. In this menu, the user can choose what lesson menu he wants to learn because there are 4 learning options buttons.

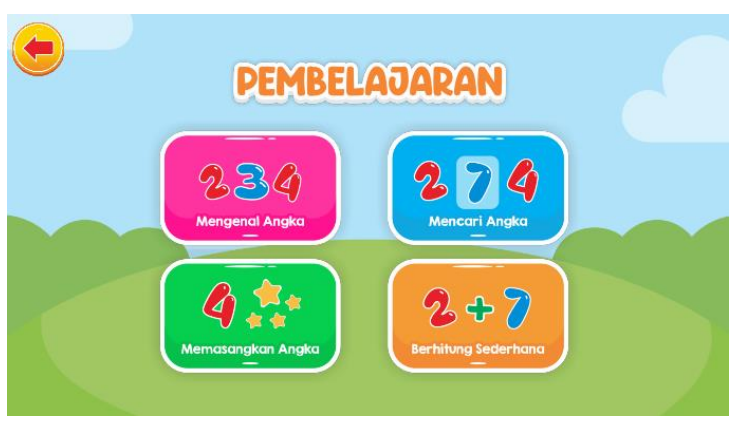

Picture 3. Learning Menu Display

The display of recognizing numbers is one of the learning menus to introduce numbers to students who choose the menu to recognize numbers.

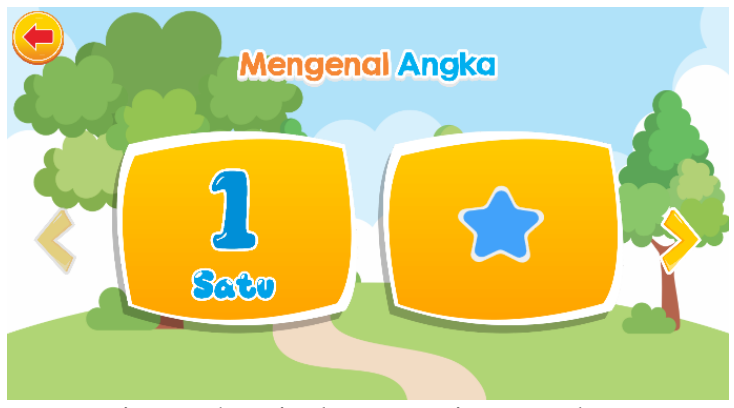

Picture 4. Display Knowing Numbers

The display of looking for numbers is one of the advanced learning menus from the menu of recognizing numbers, here students who play will be asked to look for the appropriate numbers mentioned.

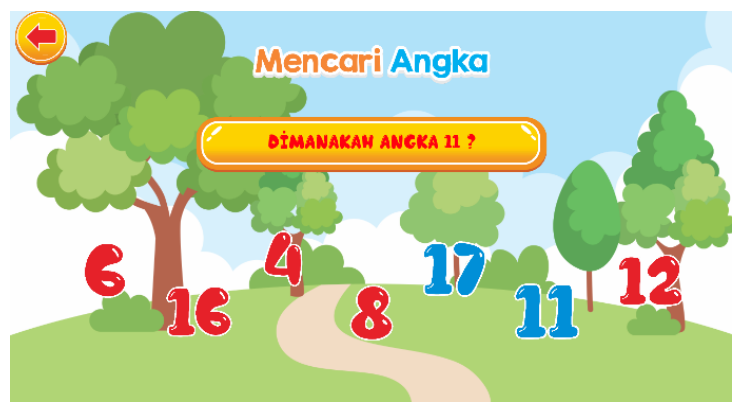

Picture 5. Display Finding Numbers

Submitted : 21-01-2021 - Accepted: 15-12-2021 - Published: 31-12-2021

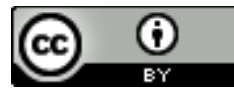

This work is licensed under a Creative Commons Attribution 4.0 International License 
Pairing numbers is one of the learning menus with the method of pairing numbers for students who learn to remember numbers better after playing pairing numbers by pairing numbers according to many stars.

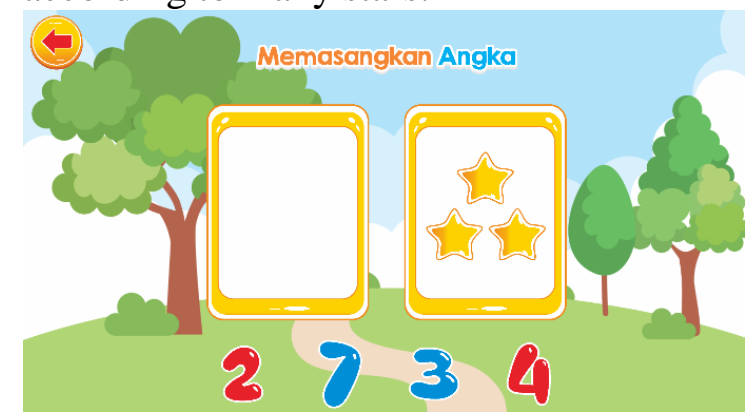

Picture 6. Display Pairing Numbers

Simple counting is the last menu in this game application. In this simple counting menu, there are 10 questions including 5 addition questions and 5 subtraction questions.

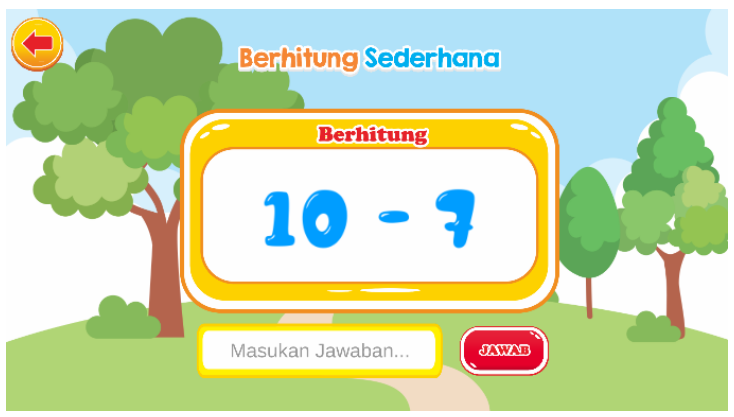

Picture 7. Simple Counting View

\section{CONCLUSION}

The Counting Learning Quiz Game Application for Kindergarten Children can be installed on the parent's smartphone given by the teacher at the Blooming Kindergarten and after being installed it can be used immediately.

\section{BIBLIOGRAPHY}

Amorim, A. N., Jeon, L., Abel, Y., Albuquerque, E. X. S., Soares, M., Silva, V. C., \& Oliveira Neto, J. R. (2022). Escribo play learning games can foster early reading and write for low-income kindergarten children. Computers \& Education, 177, 104364. https://doi.org/10.1016/J.COMPEDU. 2021.104364

Daunic, A. P., Corbett, N. L., Smith, S. W., Algina, J., Poling, D., Worth, M., Boss, D., Crews, E., \& Vezzoli, J. (2021). Efficacy of the socialemotional learning foundations curriculum for kindergarten and firstgrade students at risk for emotional and behavioral disorders. Journal of School Psychology, 86, 78-99. https://doi.org/10.1016/J.JSP.2021.03 .004

de Vries, H. G., Polk, K. D., \& Missall, K. N. (2021). Math talk during traditional and digital number board gameplay. Journal of Applied Developmental Psychology, 76, 101312. https://doi.org/10.1016/J.APPDEV.20 21.101312

Fessakis, G., Gouli, E., \& Mavroudi, E. (2013). Problem-solving by 5-6 years old kindergarten children in a computer programming environment: A case study. Computers \& Education, 63, 87-97. https://doi.org/10.1016/J.COMPEDU. 2012.11.016

Submitted : 21-01-2021 - Accepted : 15-12-2021 - Published : 31-12-2021

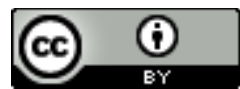

This work is licensed under a Creative Commons Attribution 4.0 International License 
Nacher, V., Garcia-Sanjuan, F., \& Jaen, J. (2016). Interactive technologies for preschool game-based instruction: Experiences and future challenges. Entertainment Computing, 17, 19-29. https://doi.org/10.1016/J.ENTCOM.2 016.07.001

Nacher, V., Jaen, J., Navarro, E., Catala, A., \& González, P. (2015). Multitouch gestures for pre-kindergarten children. International Journal of Human-Computer Studies, 73, 37-51. https://doi.org/10.1016/J.IJHCS.2014. 08.004

Nacher, V., Jurdi, S., Jaen, J., \& GarciaSanjuan, F. (2019). Exploring visual prompts for communicating directional awareness to kindergarten children. International Journal of Human-Computer Studies, 126, 14 25. https://doi.org/10.1016/J.IJHCS.2019. 01.003

Papadakis, S., Kalogiannakis, M., \& Zaranis, N. (2018). Educational Apps from the Android Google Play for Greek preschoolers: A systematic review. Computers \& Education, 116, 139-160. https://doi.org/10.1016/J.COMPEDU. 2017.09.007

Rodríguez, P., Lago, M. O., Enesco, I., \& Guerrero, S. (2013). Children's understandings of counting: Detection of errors and pseudo errors by kindergarten and primary school children. Journal of Experimental Child Psychology, 114(1), 35-46. https://doi.org/10.1016/J.JECP.2012.0 8.005
Zhang, H., \& Whitebread, D. (2017). Linking parental scaffolding with self-regulated learning in Chinese kindergarten children. Learning and Instruction, 49, 121-130. https://doi.org/10.1016/J.LEARNINS TRUC.2017.01.001

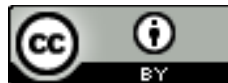

This work is licensed under a Creative Commons Attribution 4.0 International License 